\title{
Defecation rates of white-tailed deer (Odocoileus virginianus) based on fiber content in feces
}

\author{
Vega-Hernández, Dania M. ${ }^{1}$; Clemente-Sánchez, Fernando ${ }^{* 2}$; Crosby-Galván, María M. ${ }^{1}$; \\ Bárcena-Gama, Ricardo ${ }^{1}$; Olmos-Oropeza, Genaro ${ }^{2}$ \\ ${ }^{1}$ Colegio de Postgraduados, Campus Montecillo, Posgrado en Recursos Genéticos y Productividad-Ganadería, \\ Carretera México-Texcoco Km. 36.5, Municipio de Texcoco, Estado de México 56230, México. \\ 2 Maestría en Ciencias en Innovación en Manejo de Recursos Naturales, Campus San Luis Potosí, Colegio de \\ Postgraduados, Iturbide 73, Col. Centro, Salinas de Hidalgo, San Luis Potosí, 78600, México. \\ * Corresponding author: clemente@colpos.mx
}

\begin{abstract}
Objective: To develop three models to estimate the defecation rate of white-tailed deer (Odocoileus virginianus) according to the season of the year, content of neutral detergent fiber (NDF), and acid detergent fiber (ADF) in their feces.

Design/methodology/approach: Nine captive adult deer were assigned to three levels of dietary fiber. Fecal groups (defecation rate) were counted, forage consumption estimated, and feces were analyzed for their NDF and ADF content. A randomized block design was used, where the effect of the treatments was blocked by season, and a multiple regression analysis was used to define prediction models of the defecation rates.

Results: The defecation rates were different for dietary fiber levels $(\mathrm{P}<0.0001)$, and for the year season $(\mathrm{P}=0.0007)$. For spring, the defecation rate model $(\mathrm{DR})$ was $\mathrm{DR}=-4.84696-[0.02159(\mathrm{NDF})]+[0.58397$ $(\mathrm{ADF})]$; for summer $\mathrm{DR}=-51.0272+[0.26868(\mathrm{NDF})]+[1.61121(\mathrm{ADF})]$; and for winter $\mathrm{DR}=7.82939-[0.02667$ $(\mathrm{NDF})]+[0.17309(\mathrm{ADF})]$.

Limitations/implications: Defecation rate or fecal group counting is a useful tool to estimate deer populations. Nevertheless, the definition of an adequate defecation rate represents a hard task, since it depends on multiple factors such as environmental conditions and the components of the deer's diet.

Findings/conclusions: The defecation rate varies depending on the year season and the fiber content in the
\end{abstract} diet.

Keywords: Wild fauna; deer; fecal groups; intake; fiber; population.

Citation: Vega-Hernández, Dania M., Clemente-Sánchez, Fernando, CrosbyGalván, María M., Bárcena-Gama, Ricardo, \& Olmos-Oropeza, Genaro. (2021). Defecation rates of whitetailed deer (Odocoileus virginianus) based on fiber content in feces. Agro Productividad, 14(\#). https://doi. org/10.32854/agrop.v14i6.1987

Editor in Chief: Dr. Jorge Cadena Iñiguez

Estimated publication date: July 2021

This work is licensed under a Creative Commons Attribution-NonCommercial 4.0 International license

\section{INTRODUCTION}

Fecal clump counting is a component of a method frequently used to estimate deer populations in temperate and tropical forests. This method involves using defecation rate, which indicates the number of fecal clumps excreted by a deer within a 24-h period (Bennett et al., 1940; Forsyth et al., 2005; Portillo et al., 2010). Usually, defecation rates are applied to similar vegetation types where a deer population is to be estimated (Mandujano and Gallina, 1995; Beltrán-Vera and Díaz de la Vega, 2010). However, there is a large reported variation of the defecation rates which could be used (Van Etten and Bennett, 1965; Ryel, 1971; Rogers, 1987; Fuller, 1991; Härkönen and Heikkilä, 1999). The incorrect selection of a defecation rate may lead to erroneous estimates of the population density and is consequently a misleading factor in a management strategy.

Cellulose is the main polysaccharide in the cell wall of forages, and lignin is an integral component. The undigested fiber portion passes through the digestive tract and contributes to rumen filling (Moore and Jung, 2001). Van Soest et al. (1991) developed analytical methods to determine neutral detergent fiber (NDF), which is 
only partially digestible. Acid detergent fiber (ADF) residues include hemicellulose, protein, lignin and nitrogen combined with silica and pectins (Church et al., 2001). The NDF and ADF determination in forage and feces is useful since both are highly correlated with digestibility and defecation rates (McDonald et al., 2006). The objective of this research was to estimate defecation rates of white-tailed deer for their fecal NDF and ADF content, by developing models for different seasons of the year. This is a pioneering study given there are no publications on using diet components and their consumption across seasons in estimating defecation rates. The published research on defecation rates only refers to counting the number of fecal groups that a deer defecates in a 24-hour period, which is what motivated the development of the present study, involving factors specific to the feed that explain the variation and definition of defecation rates.

\section{MATERIALS AND METHODS}

The research took place in the Altiplano Potosino, Mexico, $22^{\circ} 34^{\prime} 53.9^{\prime \prime} \mathrm{N}$ and $103^{\circ}$ $38^{\prime} 41.3$ " W, with an annual rainfall of 400 to $500 \mathrm{~mm}$. The research was conducted in the Experimental Station "La Huerta" of the Colegio de Postgraduados, Campus San Luis Potosí, from December (winter) to September (summer). Nine white-tailed deer adults (one male and two females per treatment) born in captivity, were confined in individual pens $(20 \mathrm{~m} \times 10 \mathrm{~m}$ each), pre-adapted to three different diets, used as treatments (low fiber, medium fiber, and high fiber content). Three white-tailed deer (Odocoileus virginianus) were randomly assigned to each treatment (Table 1).

Table 1. Ingredients, chemical composition and fiber content of three diets used as treatments to test the effect on consumption and defecation rates in white-tailed deer.

\begin{tabular}{|c|c|c|c|c|c|c|c|}
\hline \multirow{2}{*}{ Treatments } & \multirow{2}{*}{$\begin{array}{l}\text { Ingredients } \\
\text { in diet }\end{array}$} & \multicolumn{6}{|c|}{ Chemical composition } \\
\hline & & DM \% & $\begin{array}{c}\text { Ashes } \\
\%\end{array}$ & CP \% & NDF \% & ADF \% & $\begin{array}{c}\text { Lignin } \\
\%\end{array}$ \\
\hline Low fiber level & $\begin{array}{l}\text { 100\% commercial food } \\
\text { (Trophy Maker }^{\circledast} \text { ) }\end{array}$ & 92.25 & 6.21 & 20.51 & 33.11 & 10.84 & 2.82 \\
\hline Midium fiber level & $\begin{array}{l}\text { 70\% commercial food } \\
\text { (Trophy Maker }{ }^{\circledR} \text { and } \\
\text { 30\% ground alfalfa }\end{array}$ & 98.47 & 7.06 & 19.78 & 42.13 & 17.11 & 6.26 \\
\hline High fiber level & $\begin{array}{l}\text { 30\% commercial food } \\
\text { (Trophy Maker }{ }^{\circledR} \text { ) and } \\
70 \% \text { ground alfalfa }\end{array}$ & 98.18 & 9.12 & 18.65 & 48.39 & 24.93 & 5.05 \\
\hline
\end{tabular}

$\mathrm{DM}=$ dry matter $\mathrm{CP}=$ crude protein; $\mathrm{NDF}=$ neutral detergent fiber; $\mathrm{ADF}=$ acid detergent fiber .

The assessed variables in diets as well as in the deer feces were the dry matter consumption, number of fecal groups, dry matter (DM), NDF, ADF, crude protein (CP), organic matter (OM) and lignin content.

Dry matter consumption. Forage was weighed and accessible ad libitum to each deer; the food rejected was weighed 24 hours after it was offered. Once a month, the consumption was calculated by the weight difference. The daily consumption of dry 
matter was estimated based on the DM content in the diet, according to the result of the chemical analysis of the diet.

Defecation rate. Each deer was under direct observation once a week for a continuous 24-hour period from December to September. All the times a deer defecated were recorded. At the end of 24 hours, all fecal groups were collected to verify that the total was equal to the number of fecal groups obtained by direct observation. Verification was possible because individual pens were cleaned removing all accumulated fecal groups before the continuous 24 hours of observation. All the collected fecal groups were dried in a forced-air oven at $55^{\circ} \mathrm{C}$ and ground in a Wiley mill with a $1 \mathrm{~mm}$ mesh for their chemical analysis.

Chemical analysis. From the total fecal groups collected, a sample ( $\mathrm{n}=200$ ) was used for laboratory analysis, as well as another similar sample for the analysis of the diets. In the laboratory, The DM, OM, CP and ash content were determined in the laboratory, following the procedures of the AOAC (2005). The NDF, ADF and lignin contents were analyzed following the procedures described by Van Soest et al. (1991).

Statistical analysis. To assess the effect of the fiber level on food intake and the defecation rate during spring, summer and winter, an ANOVA was carried out under a randomized complete block design, where the treatments corresponded to the three fiber levels in diets, blocked by the three seasons considered in this research. Once the season and fiber level were determined to be factors that defined forage intake and defecation rate, defecation rate models were constructed using multiple regression analysis for both NDF and ADF in feces and its corresponding rate of defecation. The statistical analyses were performed using the SAS statistical software (v. 9.0).

\section{RESULTS AND DISCUSSION}

Daily DM intake ranged from 0.37 to $2.14 \mathrm{~kg}$ per deer. Feed intake was affected $(\mathrm{P}=0.0006)$ by the dietary fiber level and by the season $(\mathrm{P}<0.0001)$. The lowest $\mathrm{DM}$ intake occurred in winter $(0.37 \mathrm{~kg})$, the highest in summer $(2.14 \mathrm{~kg})$. Deer consuming the low-fiber diet averaged $1.01 \mathrm{~kg}( \pm 0.41)$ of DM intake, while the medium-fiber diet averaged $1.09 \mathrm{~kg}( \pm 0.28)$, the high-fiber diet averaged $0.85 \mathrm{~kg}( \pm 0.21)$. The range of feed intake reported by Short et al. (1969) was 0.47 to $0.98 \mathrm{~kg}$, while Ruggiero and James (1976) reported daily intakes of $1.03 \mathrm{~kg}( \pm 0.14)$ and $1.78 \mathrm{~kg}( \pm 0.37)$ for males. Holter et al. (1977) reported the season effect on food intake and body weight in white-tailed deer, and detected a reduction in forage intake during winter, increasing in spring and summer. Differences in food intake throughout the year are determined by behavioral mechanisms and morphological and physiological changes related to photoperiod at varying endocrine levels (Bailey and Brown, 2011), as well as other factors such as digestive disorders, feeding frequency, forage processing, diet-associated effects, environmental factors, and the ability of different species to digest a particular forage, especially high-fiber forage (Church et al., 2001).

The effect of dietary fiber level on the defecation rate showed a difference $(\mathrm{P}<0.0001)$, as well as between seasons $(\mathrm{P}=0.0007)$. The average daily defecation 
rate for deer consuming low fiber was 10 fecal clumps ( \pm 3.48$)$, while for deer consuming a medium fiber diet it was 16 clumps ( \pm 4.70$)$, and for the high fiber diet, the defecation rate was 15 ( \pm 4.18$)$. At the end of summer, vegetation begins to decrease in its nutritional quality (Clemente et al., 2005; Dostaler et al., 2011). Then, deer show changes in DM intake as the amount of dietary fiber varies, because, as forage matures, its digestibility, protein, mineral, and soluble carbohydrate content decreases, while cell wall constituents increase (Vangilder et al., 1982). Johnson et al. (1998) found a linear reduction in protein and OM as well as NDF and ADF as the diet increased. Similar information in other grazing ruminants has been reported, where NDF and DM also increased as the season progressed, and because shrubs are more lignified in winter, defecation rates and feed passage significantly decreased (Rogers, 1987). Our results show that during spring the defecation rate was $14( \pm 4.82)$, in summer $15( \pm 4.26)$ and $12( \pm 4.85)$ in winter.

Results to determine the relationship between fiber content and defecation rate showed that the NDF percentage in feces ranged from $47.01 \%$ to $70.22 \%,(\bar{x}=55.91 \%)$ $( \pm 4.02)$. Neutral detergent fiber in feces increased $(\mathrm{p}<0.0001)$ as dietary fiber level increased. Neutral detergent fiber found in the feces with low fiber diet was $54.11 \%$ $( \pm 3.50)$, while for medium fiber diet, 57.51\% ( \pm 4.15$)$ and $57.40 \%( \pm 2.92)$ for high fiber diet. Acid detergent fiber also showed differences $(\mathrm{P}<0.0001)$ according to the dietary fiber levels. Acid detergent fiber in fecal groups with low fiber diet averaged $27.42 \%$ ( \pm 2.02$)$, while with medium fiber diet 33.86\% ( \pm 3.17$)$ and $36.51 \%( \pm 1.92)$ for high fiber diet. The forage intake level affects the defecation rate in deer, and the type of forage affects forage intake (Smith, 1964). Showers et al. (2006) reported that in whitetailed deer with high fiber digestibility levels, feed intake decreases, and with low digestibility, DM intake increases. The negative relationship between NDF and feed intake indicates that at low forage intake in the digestive tract, the filling capacity has been reached (Gray and Sarvello, 1995). This is confirmed in this study, because as fiber increased in the diet, feed intake decreased, confirming significant changes in the seasonal defecation rate. Rogers (1987) found a defecation rate increase in whitetailed deer during spring and summer seasons, and lower values during winter. In this regard, Van Etten and Bennett (1965) observed differences in the total number of deer fecal groups collected in different seasons, reporting 869 fecal groups in spring and 682 groups in autumn. Sawyer et al. (1990) estimated an average defecation rate of 12 fecal groups, which increased to 34 in the fall. In other studies, Perez et al. (2006) found a high coefficient of variation in the number of fecal groups for white-tailed deer; daily fecal groups ranged from 8 to 25 and from 5 to 28.

In this research we found that fiber and season were the main factors affecting the defecation rate. To estimate the defecation rate (DR), multiple regression analysis provided three prediction models. For spring the model was $\mathrm{DR}=-4.84696-[0.02159$ $(\mathrm{NDF})]+[0.58397(\mathrm{ADF})]$; for summer, the model was $\mathrm{DR}=-51.0272+[0.26868$ $(\mathrm{NDF})]+[1.61121(\mathrm{ADF})]$; and for winter the model was $\mathrm{DR}=7.82939-[0.02667$ $(\mathrm{NDF})]+[0.17309(\mathrm{ADF})]$ (Table 2). 
Table 2. Prediction equations of defecation rates (DR) of white-tailed deer, from the contents of neutral detergent fiber (NDF) and acid detergent fiber (ADF) in feces.

\begin{tabular}{cc|c}
\hline Prediction equation & $\mathbf{r}^{\mathbf{2}}$ & Season of the year \\
\hline $\mathrm{DR}=-4.84696-[0.02159(\mathrm{NDF})]+[0.58397(\mathrm{ADF})]$ & 0.91 & Spring \\
\hline $\mathrm{DR}=-51.0272+[0.26868(\mathrm{NDF})]+[1.61121(\mathrm{ADF})]$ & 0.89 & Summer \\
\hline $\mathrm{DR}=7.82939-[0.02667(\mathrm{NDF})]+[0.17309(\mathrm{ADF})]$ & 0.87 & Winter \\
\hline
\end{tabular}

$\mathrm{DR}=$ defecation rate; $\mathrm{NDF}=$ percentage of neutral detergent fiber in feces; $\mathrm{ADF}=$ percent of acid detergent fiber in feces.

The models developed in this study can be applied by wildlife managers in other study areas under different ecological conditions since changes in defecation rates directly relates to dietary fiber contents, which are affected by changes in the botanical composition of the intake and by different environmental conditions in the ecosystems. Therefore, our results support the hypothesis that the defecation rate of white-tailed deer differs according to the season of recollection of fecal groups and their fiber contents. Season and rainfall are indirect factors affecting the defecation rate. The physiological state of a plant is highly correlated with its fiber content, and it determines the consumption level and, therefore, the rate of defecation.

\section{CONCLUSIONS}

Food intake in white-tailed deer seasonally varies according to dietary fiber content, due to the dietary variation resulting from changes in the climatic conditions, leading to changes in defecation rate. The defecation rate of white-tailed deer in winter significantly decreases due to lower forage intake. Defecation rate can be predicted for a particular season in areas where fresh fecal clumps are collected based on NDF and ADF content, regardless of habitat type. The models for predicting defecation rate in white-tailed deer obtained in this research are a tool to reduce error in estimating wild population densities.

\section{ACKNOWLEDGMENTS}

To the Master's Program in Innovation in Natural Resources Management, the Assisted Reproduction Laboratory and the Deer Production Module of the Experimental Station "La Huerta" of the Campus San Luis Potosi of the Colegio de Postgraduados for the facilities and economic support to carry out this study. To the Programa de Recursos Genéticos y Productividad-Ganadería and the Laboratorio de Nutrición Animal del Campus Montecillo del Colegio de Postgraduados for their support in the chemical analysis of the samples.

\section{REFERENCES}

Bailey, D. W. \& Brown, J. R. (2011). Rotational Grazing Systems and Livestock

Grazing Behavior in Shrub-Dominated Semi-Arid and Arid Rangelands. Rangeland Ecology and Management 64:1-9.

Beltran-Vera, C.Y. y Diaz de la Vega, M. (2010). Estimación de la densidad poblacional del venado cola blanca texano (Odocoileus virginianus texanus), introducido en la UMA “Ejido de Amanalco" Estado de México. Universidad Autónoma del Estado de México: Revista Ciencia Ergo Sum 17:154-158.

Bennett, L. J., English, P. F., \& McCain, R. (1940). A study of deer populations by use of pellet group counts. Journal of Wildlife Management 4:398-403. 
Clemente, F., Riquelme, E., Mendoza, G. D., Barcena, R., Gonzalez, S., \& Ricalde, R. (2005). Digestibility of forage diets of whitetailed deer (Odocoileus virginianus, Hays) using different ruminal fluid innocula. Journal of Applied Animal Research 27:71-76.

Church, D. C., Pond, W. G., \& Pond, K. R. (2001). Fundamentos de nutrición y alimentación de animales. Mexico (DF): $2^{\mathrm{a}}$ Edición. Editorial Limusa-Wiley.

Dostaler, S., Quellet, J. P., Therrien, J. F., \& Cote, S. D. (2011). Are feeding preferences of white-tailed deer related to plant constituents Journal of Wildlife Management 75:913-918.

Fuller, T. K. (1991). Do pellet counts index white-tailed deer numbers and population change? Journal of Wildlife Management 55:393-396.

Forsyth, D. M., Barker, R. J., Morris, G., \& Scroggie, M. P. (2005). Modeling relationship between fecal pellets indices and deer density. Journal of Wildlife Management 71:964-970.

Gray, P. B., \& Sarvello, F. A. (1995). Energy intake relationships for white-tailed deer on winter browse diets. Journal of Wildlife Management 59:147-152.

Härkönen, S., \& Heikkilä, R. (1999). Use of pellet group counts in determining density and habitat use of moose (Alces alces) in Finland. Journal of Wildlife Biology 5:233-239.

Holter, J. B., Urban, W. E., \& Hayes, H. H. (1977). Nutrition of Northern white-tailed deer throughout the year. Journal of Animal Science 45:365-376.

Johnson, J. A, Caton, J. S., Poland, W., Kirby, D. R., \& Dhuyvetter, D. V. (1998). Influence of season on dietary composition, intake and digestion in beer steers grazing mixed grass prairie in the northern Great Plains. Journal of Animal Science 76:1682-1690.

Mandujano, S., \& Gallina, S. (1995). Comparison of deer censuring methods in tropical dry forest. Wildlife Society Bulletin 23:180-186.

McDonald, P.; Edwards, R. A.; Greenhalg, J. F. D.; \& Morgan, C. A. (2006). Nutrición Animal. Editorial Acribia S.A. $6^{a}$ Edición. Zaragoza, España.

Moore, J., \& Jung, H.J.G. (2001). Lignin and Fiber Digestion. Journal of Range Management 54:420-430.

Pérez, S., Mandujano, S., \& Martínez, R. E. (2006). Tasa de defecación del venado cola blanca, (Odocoileus virginianus mexicanus), en cautividad en Puebla, México. Acta Zoológica Mexicana 20:167-170.

Portillo, R. H. O., Hernández, J., Elvír, F., Leiva, F., \& Martínez, I. (2010). Estimación de la tasa de defecación del venado cola blanca Odocoileus virginianus en cautividad en Honduras. Mesoamericana 1:55-57.

Rogers, L. L. (1987). Seasonal changes in defecation rates of free ranging white-tailed deer. Journal of Wildlife Management 51:330-333.

Ruggiero, L. F., \& James, B. W. (1976). A comparison of in vitro and in vivo feed digestibility by white-tailed deer. Journal of Range Management 29:82-83.

Sawyer, T. G., Marchinton, R. L., \& Maclentz, W. (1990). Defecation rates of female white-tailed deer in Georgia. Wildlife Society Bulletin. 18:16-18.

Short, H. L., Newsom, J. D., McCoy, G. L., \& Fowler, J. F. (1969). Effects of nutrition and climate on southern deer. Transactions the North American Wildlife and Natural Resources Conference 34:137-146.

Showers, S. E., Tolleson, D. R., Stuth, J. W., Kroll, J. C. \& Koerth, B. H. (2006). Predicting Diet Quality of White-Tailed Deer via NIRS Fecal Profiling. Rangeland Ecology \& Management 59:300-307.

Smith, A. (1964). Defecation rates of mule deer. Journal of Wildlife Management. 28:435-444. Vangilder, L. D., Torgerson, O., y Porath, W. R. 1982. Factors influencing diet Selection by white-tailed deer. Journal of Wildlife Management 46:711-718.

Van Etten, R. C., \& Bennett, C. L. (1965). Some sources of error in using pellet-group counts for censusing deer. Journal of Wildlife Management 29:723-729.

Van Soest, P. J., Robertson, J. B., \& Lewis, B. A. (1991). Methods for dietary fiber, neutral detergent fiber and non-starch polysaccharides in relation to animal nutrition. Journal of Dairy Science 74:3583-3597. 